\title{
The Production of Nickel-Chromium-Molybdenum Alloy with Open Pore Structure as an Implant and the Investigation of Its Biocompatibility In Vivo
}

\author{
Yusuf $\mathrm{Er}^{1}$ and Emine Unsaldi ${ }^{2}$ \\ ${ }^{1}$ Department of Metallurgy Education, Gazi Vocational High School, Directorate of National Education, 23100 Elazig, Turkey \\ ${ }^{2}$ Department of Surgery, Faculty of Veterinary, Firat University, 23119 Elazig, Turkey
}

Correspondence should be addressed to Yusuf Er; yusufer23@hotmail.com

Received 29 January 2013; Accepted 21 March 2013

Academic Editor: Hamdy Doweidar

Copyright (C) 2013 Y. Er and E. Unsaldi. This is an open access article distributed under the Creative Commons Attribution License, which permits unrestricted use, distribution, and reproduction in any medium, provided the original work is properly cited.

\begin{abstract}
A dental crown material, Nickel-Chrome-Molybdenum alloy, is manufactured using precision casting method from a polyurethane foam model in a regular and open-pore form, as a hard tissue implant for orthopedic applications. The samples produced have 10, 20, and $30( \pm 3)$ pores per inch of pore densities and $0.0008,0.0017$, and $0.0027 \mathrm{~g} / \mathrm{mm}^{3}$ densities, respectively. Samples were implanted in six dogs and observed for a period of two, four, and six months for the histopathological examinations. The dogs were examined radiologically in 15-day intervals and clinically in certain intervals. The implants were taken out with surrounding tissue at the end of these periods. Implants and surrounding tissues were examined histopathologically in terms of biocompatibility. As a result, it is seen that new bone tissue was formed, in pores of the porous implant at the head of the tibia in dogs implanted. Any pathology, inflammation, and reaction in old and new tissues were not observed. It was concluded that a dental alloy (Ni-Cr-Mo alloy) could also be used as a biocompatible hard tissue implant material for orthopedics.
\end{abstract}

\section{Introduction}

In recent years, many developments have taken place in the field of orthopedics; the most important developments, without doubt, are in the field of implantology. The materials used in implantology are subjected to very hard conditions in vivo $[1,2]$. The properties of the material, design, and method of fixation of the implant determine the performance. Strength, fatigue, surface corrosion, allergic reactions caused, and totally biocompatibility of the biomaterials used are the main research subjects today [2-4].

Many different materials have been used as bone implants. An ideal hard tissue implant must be fully compatible and biologically inert, be easy to be found, have strength close to the bone strength, and should be accepted or rejected by the patient's tissue without infection. Biocompatible implants, because of their open-cellular structure, permit the ingrowths of the new bone and transport of the body fluids [5-7]. Serious problems are due to implant-bone interphase in the field of implantology [4]. Therefore, there is a need to develop high biocompatible new implant materials. Porous materials enable osseous tissue into the implant. Investigations have shown that the average pore size of the porous bone substitute material implanted must have pore size to allow the advancement of the bone tissue ingrowth. This size should be approximately 200 to $500 \mu \mathrm{m}$ [6-8]. Metallic foams are new class of materials with extremely low densities and unique combination of excellent mechanical, thermal, electrical, and acoustic properties [7, 9]. It is especially attractive that the strength and the Young's modulus of the cellular materials can be adjusted through the adjustment of the porosity to match the strength and the Young's modulus of the natural bone. Hence it is indispensable to develop new bone-substitute materials with high strength and appropriate Young's modulus to ensure the biomechanical properties of the natural bones [7].

In the present study, a Nickel-based a Ni-Cr-Mo alloy widely used in the construction of dental prostheses was used to produce the samples by precision casting method [9-13] with different open pore sizes. Furthermore, the usability as 
an orthopedic implant material and biocompatibility in vivo conditions were investigated.

\section{Materials and Methods}

2.1. The Production of Implant Samples. Nickel-based alloys are used as implant materials. The alloy which was used in this study is commercially produced by the German company Böhler. In Table 1, the chemical composition is given by the manufacturer. In the production of the samples, a two-stage casting method was used. In this method, the open cell metal foams are produced by using polymeric foams. Here, polyurethane foams with open pores in three different sizes were used as a sample model. The produced sample models have 10,20 , and $30( \pm 3)$ pores per inch (ppi) and 0.0008, 0.0017 , and $0.0027 \mathrm{~g} / \mathrm{mm}^{3}$ densities, respectively. Molds were prepared by pouring precision casting plaster into the mold cavities. Prepared molds were heated for 1 hour at $1000^{\circ} \mathrm{C}$ in a thermocouple equipped oven for the preparation of precast. In this way, the cast cavity has been created in the mold by burning out polyurethane foams. Then the alloy is heated up to $1410^{\circ} \mathrm{C}$ and poured into molds by using a centrifugal casting device. Molds were left to cool down and then were broken and cleaned to remove the case. A sufficient number of samples (Figures 1(a) and 1(b)) were produced in this way.

2.2. Preparation of Experimental Subject Materials. Six healthy dogs were used as an experimental subject material of different breed, age, sex, and weight 27 to $35 \mathrm{~kg}$. Preventative rabies vaccines, endo- and ectoparasitic drug applications were performed prior to the operation. Soft tissue operation sets, orthopedic sets, drill bit, and the curette were used for operations.

2.3. Method. The anesthesia was performed with i.m. injection of $15 \mathrm{mg} / \mathrm{kg}$ ketamine hydrochloride 10 minutes after administration of i.m. $1.5 \mathrm{~mL} / 10$ Xylazine hydrochloride (Rompun, Bayer). The implants produced for the study were applied to the proximal metaphysis of the tibia. A maximum care was paid to asepsis and antisepsis procedures during the study. The implants were applied to randomly selected tibias. The skin incision was extended from the tuberosity of the tibia to the crista tibialis. Following exclusion of the skin and underlying tissues, the periosteum was elevated performing a $2-3 \mathrm{~cm}$ incision. After lifting the periosteum with an elevator, the bone cortex was perforated with an aid of a 5 diameter Steinmann pin. The holes established in the bones were readjusted to the implants' sizes using different size drills and bone curettes. For insertion the implants, some spongiosis bone graft was removed from the window established in the cortex with a curette and then they were carefully placed in the defects performed (Figures 2(a) and 2(b)).

2.4. Postoperative Applications. Operation wound was closed by the conventional operational techniques. All cases were examined radiographically immediately after the operations. Antibiotics were parenterally administered for five days in order to prevent possible postoperative infections. The dogs
TABLE 1: Alloy chemical composition.

\begin{tabular}{lc}
\hline Content & Mixing ratio \\
\hline Nickel & Bal. \\
Chromium & 26.0 \\
Molybdenum & 11.0 \\
Silicon & 1.5 \\
Carbon & $<0.05$ \\
\hline
\end{tabular}

TABLE 2: Average porosities of the samples by groups.

\begin{tabular}{lcccc}
\hline $\begin{array}{l}\text { Samples } \\
\text { groups }\end{array}$ & $\begin{array}{c}\text { (1) Sample } \\
\text { porous } \\
\text { average (\%) }\end{array}$ & $\begin{array}{c}\text { (2) Sample } \\
\text { porous } \\
\text { average (\%) }\end{array}$ & $\begin{array}{c}\text { (3) Sample } \\
\text { porous } \\
\text { average (\%) }\end{array}$ & $\begin{array}{c}\text { General } \\
\text { porous } \\
\text { average (\%) }\end{array}$ \\
\hline A & 89.6 & 91 & 91.5 & 90.7 \\
B & 78.9 & 80.3 & 83.8 & 81 \\
C & 66.8 & 68.1 & 72.8 & 68.8 \\
\hline
\end{tabular}

TABLE 3: General porosities by the pore sizes.

\begin{tabular}{lcccc}
\hline $\begin{array}{l}\text { Samples } \\
\text { groups }\end{array}$ & $\begin{array}{c}\text { Pore sizes } \\
(\mathrm{ppi})\end{array}$ & $\begin{array}{c}\text { Solid } \\
\text { densities } \\
\left(\mathrm{g} / \mathrm{mm}^{3}\right) \\
\left(\rho_{\text {solid }}\right)\end{array}$ & $\begin{array}{c}\text { Porous } \\
\text { densities } \\
\left(\mathrm{g} / \mathrm{mm}^{3}\right) \\
\left(\rho_{\text {porous }}\right)\end{array}$ & $\begin{array}{c}\text { General } \\
\text { porosities } \\
\text { in percent } \\
(\varepsilon)(\%)\end{array}$ \\
\hline A & $10( \pm 3)$ & 0.0088 & 0.0008 & 90.7 \\
B & $20( \pm 3)$ & 0.0088 & 0.0017 & 81 \\
C & $30( \pm 3)$ & 0.0088 & 0.0027 & 68.8 \\
\hline
\end{tabular}

were investigated radiographically and clinically checked in fifteen-day intervals. The implants and surrounding tissue were taken out with all tibias second, fourth, and sixth months after the implantation, respectively. Implants with surrounding tissue were fixed in $10 \%$ paraformaldehyde for 48 hours and then for decalcified were kept in 10\% formic acid for 15 days, dehydrated for one hour with water, and embedded in wax. 4 micrometer thick sections were cut by microtom and stained with haematoxylin-eosin. The sections were viewed and photographed using a KyowaTokyo microscope.

\section{Results}

3.1. Materials Characterization. In this study, the densities and average porosities of the samples produced in the dimensions of $\phi 12 \times 14 \mathrm{~mm}$ with three different pore sizes were calculated (Table 2). Pore size was determined by the porous per inch (ppi). Since the samples have open pores, the volume was found by liquid weighing method. Porous densities $\left(\rho_{\text {porous }}\right)$ were found from the relation between mass $(m)$ and volume $(v)$ given in (a). Then porosities in percent $(\varepsilon)$ were calculated by the formulae given in (b) by full densities and porous densities of the samples. The solid density of the alloy used, the pore sizes, porous densities, and average 


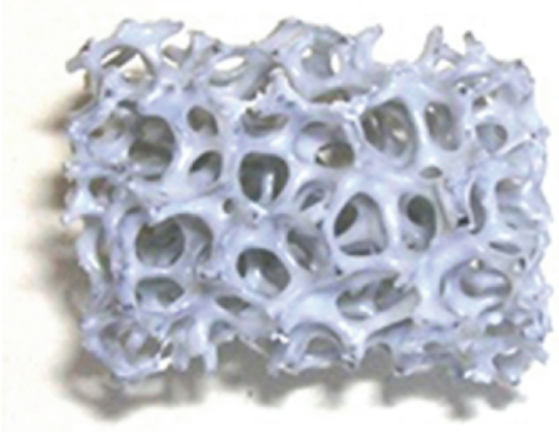

(a)

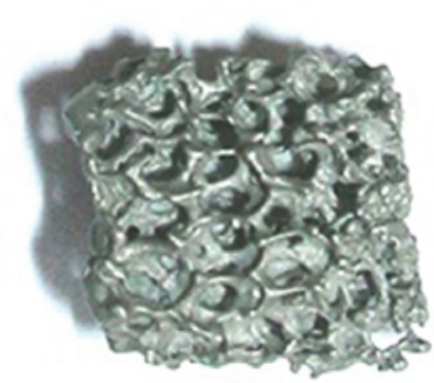

(b)

Figure 1: (a) Polyurethane foam model. (b) Produced sample.

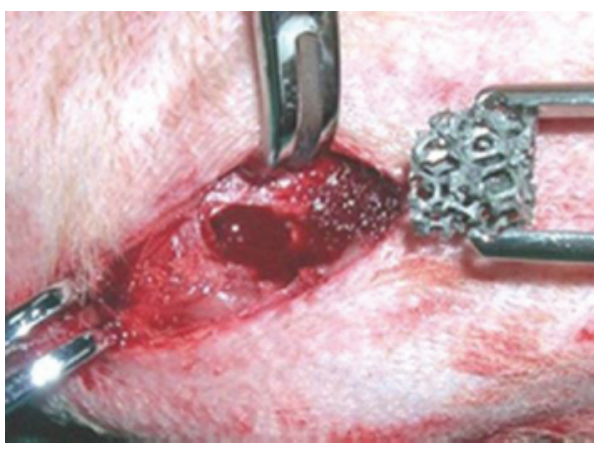

(a)

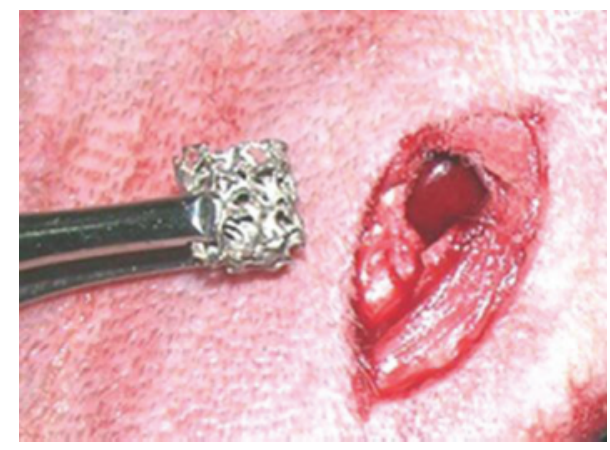

(b)

FIgURE 2: Placement of the sample.

percent porosities of the samples were given in Table 3 as follows:

$$
\begin{gathered}
\rho_{\text {porous }}=\frac{m}{v}, \\
\varepsilon=\left(1-\frac{\rho_{p}}{\rho_{s}}\right) \times 100 .
\end{gathered}
$$

When percent porosity, densities, and porosity ratios given in Table 3 were evaluated together, it is seen that group A samples have maximum pore size and average pore amount. The number of pore in inch in this group is $10( \pm 3)$. These properties were adjusted by changing the diameter of the wires connecting pores in polyurethane model before casting. The samples in group B having a pore number of 20 $( \pm 3)$, the amount of pores decreases with regard to the one of the group A samples. It is quite natural that porous densities of the samples in the same dimensions decrease proportional to the pore rates. The reason for the irregular change in the average porosity of the samples in three different groups is due to the difference in the branches of the wires among the pores in models.

3.2. Radiography. Implants in vivo were radiographically examined in 2 th, 4 th, and 6 th postoperative months and the graphs are given in Figures 3(a)-3(c). No pathologic symptoms and reaction were observed within the implanted area.

3.3. Macroscopy. In macroscopic examination of tibias in postoperative 2, 4, and 6 months just immediately after euthanasia, it was seen that the implant area and the pores of the implant were covered by the bone tissue completely. Figure 4 shows the pores full of bone tissue in the cross sectional area of the implant.

3.4. Microscopy. In the light microscopy of all tissue examples taken from all the groups in postoperative periods, no immunological reaction and inflammatory cell infiltration were observed. Osteoblastic activity increased and osteocytes became increasingly evident from 2 nd month to 6th month and gained normal bone tissue appearance in the end of the 6th month. Not one of the bone examples taken from all the samples had active inflammation, chronic infection, osteomyelitis, foreign object granuloma, giant cell reactions, benign or malign tumor, and definite tissue necrosis observed. In Figure 5(a), the number of osteocyte is low and no clear osteoblastic activity is seen. Similarly both the number of the osteocytes is low and osteoblast activity is poor at the end of the 2 nd postoperative month. No immunological reaction is seen in periosteum in Figure 5(b) but osteoblast activity. More osteocytes are seen in comparison to the 2nd 


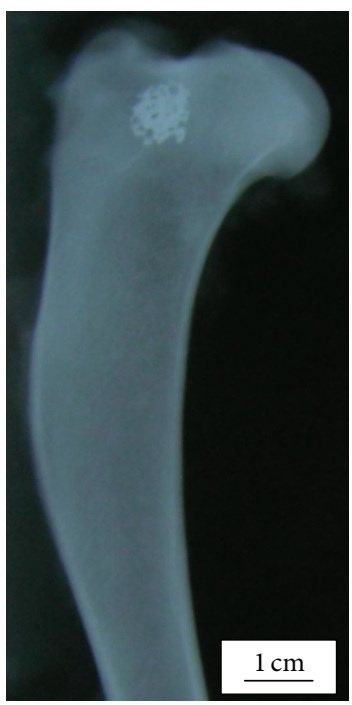

(a)

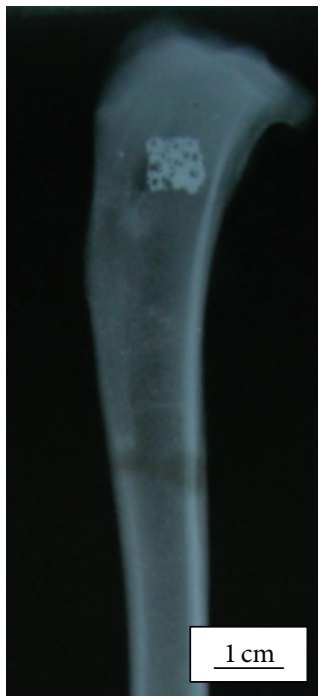

(b)

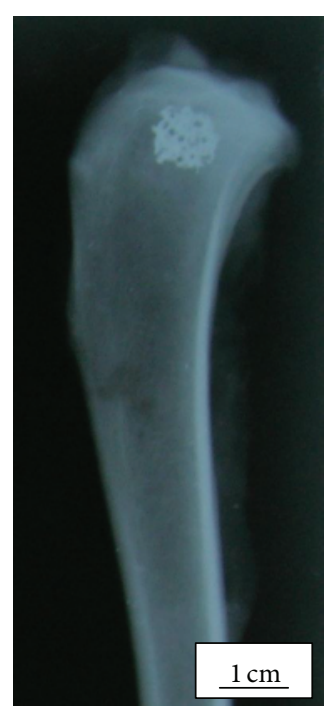

(c)

Figure 3: (a, b, c) 2nd, 4th, and 6th month radiography.

TABLE 4: Mechanic properties of some different alloys and bone.

\begin{tabular}{|c|c|c|c|c|c|c|}
\hline Material & Form & $\begin{array}{l}\text { Solid density } \\
\left(\mathrm{g} / \mathrm{cm}^{3}\right)\end{array}$ & $\begin{array}{l}\text { Elastic modulus } \\
\quad(\mathrm{GPa})\end{array}$ & $\begin{array}{l}\text { Yield strength } \\
\quad(\mathrm{MPa})\end{array}$ & $\begin{array}{c}\text { General porosities in percent } \\
(\%)\end{array}$ & References \\
\hline Co-Cr-Mo & Solid & $8.3-8.6$ & $200-230$ & 275-1585 & - & {$[14]$} \\
\hline $316 \mathrm{~L}$ & Solid & 8 & 200 & $170-750$ & - & {$[14]$} \\
\hline Ti-6Al-4V & Solid & - & 110 & $850-900$ & - & {$[14]$} \\
\hline Hidroksiyapatit & Solid & 3.2 & - & 279 & - & {$[2]$} \\
\hline $\mathrm{Ni}-21 \mathrm{Cr}-9 \mathrm{Mo}-4 \mathrm{Nb}$ & Porous & - & $0.77-1.87$ & $1.28-3.48$ & $6.84-10.71$ & {$[13]$} \\
\hline $\mathrm{Ni}-\mathrm{Cr}-\mathrm{Mo}$ & Porous & 8.8 & $0.078-0.54$ & $2.05-13.54$ & $68.8-90.7$ & This study \\
\hline Bone & Porous & 2.1 & $10-40$ & 20 & 5-95 & [14] \\
\hline
\end{tabular}

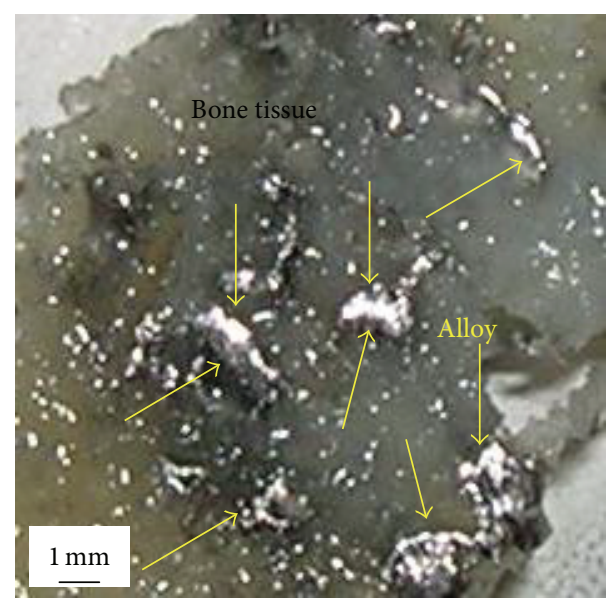

FIgURE 4: View of the sample in the bone tissue.

month. At the end of the 4th month osteoblasts are observed clearly as seen in Figures 5(c) and 5(d). Figure 5(e) shows normal bone tissue, osteoblast activity, and healthy periosteum with no immunological reaction at the end of the 6th postoperative month. Normal periosteum and spongiosis bone structure are seen in Figure 5(f). No immunological reaction and inflammatory cell infiltration are seen in the periosteal region (Figure 5(g)).

\section{Discussion and Conclusion}

In this study, a Ni-based Ni-Cr-Mo alloy which is commonly used in the orthopedic and dental field was used to produce the samples as an implant material and was composed with the precision cast method. The samples had an open porosity structure, various pore sizes, and filamentary gauges. The produced samples were implanted in dogs for various periods, the biocompatible process was examined in vivo conditions, and the following results were obtained.

The material used for the production method was according to Curran, [15]; the endurance of the foams obtained with metal powder and the powder metallurgy method was related with the tiniest spots between the metal or granules. He has noted that the specific endurance of foams produced by powder metallurgy would be low in accordance with 


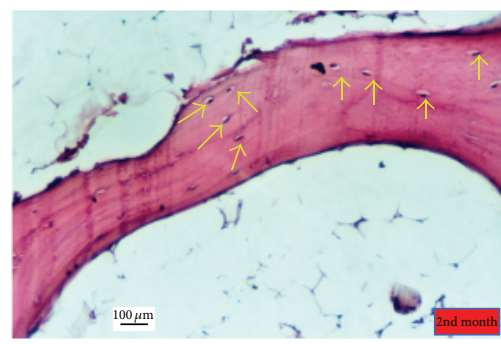

$\longrightarrow$ Osteosit

(a)

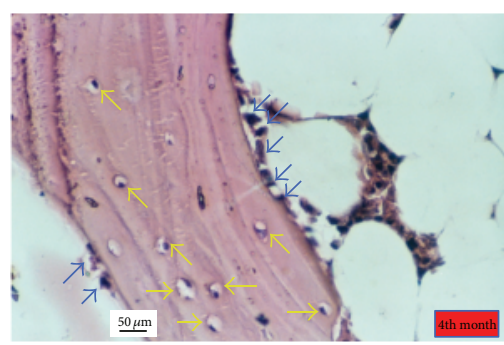

$\longrightarrow$ Osteosit

(c)

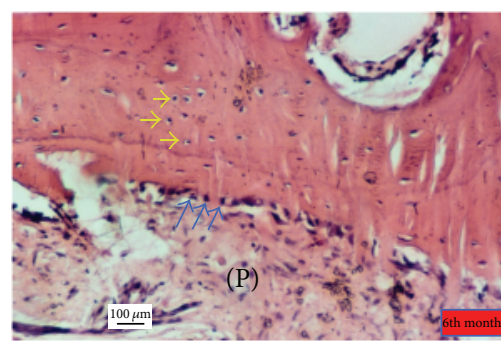

$\longrightarrow$ Osteoblast

(P) Periost

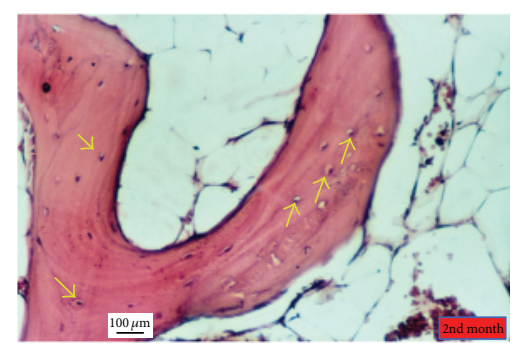

(b)

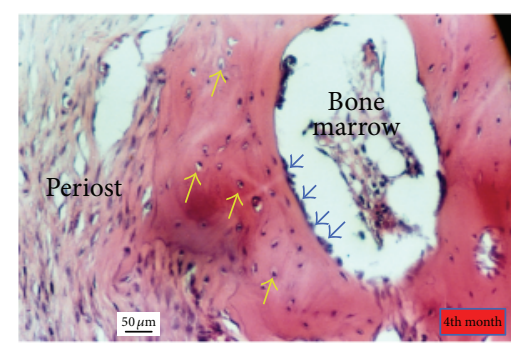

$\rightarrow$ Osteosit

(d)

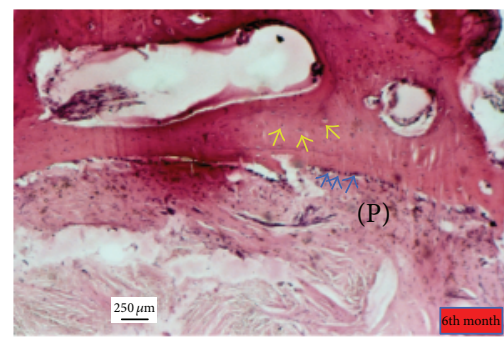

$\longrightarrow$ Osteoblast

(P) Periost

(e)

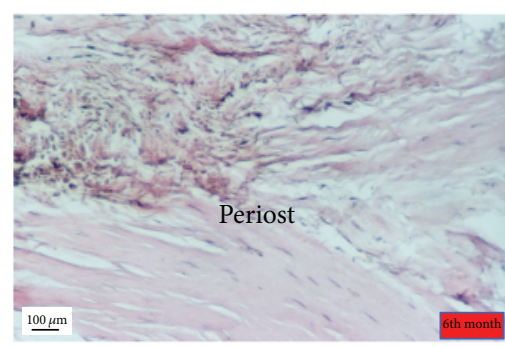

(g)

Figure 5: (a, b) Poor osteoblast activity at the end of the 2nd postoperative month. (c, d) At the end of the 4th month osteoblasts are clearly observed. (e, f) More osteoblast activity and healthy periosteum with no immunological reaction at the end of the 6th postoperative month. (g) Normal periosteum and spongiosis bone structure. 
their production method. Yamada et al. [12] reported that a casting with an open pore structure was materialized with the infiltration method using a polyurethane foam model, and it was noted that the materials used for the production were of high quality and reliable, and the porosity rate can climb up to $98 \%$. Yamada et al. also reported that any alloy or metal could be cast by this method. Yamada et al. [12] used Al and $\mathrm{Mg}$ materials to produce samples with a polyurethane foam model in their study. They derived relative density ratios as $\mathrm{Al} ; 0.0446-0.0653, \mathrm{Mg} ; 0.0282-0.0306$. A centrifugal casting device was used in this study alternatively for the infiltration casting of Yamada et al. [12]. Bone growth into porous metal surfaces depends on several factors including the porosity of the surface [16-18]. The controllability of the pore sizes and the filamentary sections of the samples which were produced with the precision casting method can be observed in the centrifugal casting device. Pores with uniform structure were obtained by using the polyurethane foam model. All the pores resemble the polyurethane foam pores used as model. Porous implants having densities between $0.0008 \mathrm{~g} / \mathrm{mm}^{3}$ and $0.0027 \mathrm{~g} / \mathrm{mm}^{3}$ were obtained from an alloy of Ni-Cr-Mo with a solid density of $0.0088 \mathrm{~g} / \mathrm{mm}^{3}$. Solid and porous densities and Young's modulus of some biomaterials and bone itself are given together with the results of this study in Table 4 for comparison.

There are big differences between Young's modulus and compressive strengths of solid and porous materials as seen in Table 4 . Human bone has much less density $\left(2.1 \mathrm{~g} / \mathrm{cm}^{3}\right)$ than porous metallic implant materials but higher Young's modulus and compressive strength indicating a tougher structure. The porosity of human bone changes in different parts of body. The locations where bone is subjected to excessive, compressive, or impact loads are less porous and consequently have higher compression strength and Young's modulus.

The materials, which were produced porous, it is observed that they display a relative attitude to the bone attitudes in terms of the density, elasticity, and stress values in accordance with the materials produced nonporous. The density values of the samples were examined; the pore size and the filamentary section caused the increase of the relative density. These values show that porous structures are more proper in terms of using biomaterial. The Ni-Cr-Mo and Ni-21Cr-9Mo- $4 \mathrm{Nb}$ alloys were produced by applying the polyurethane foam model method, and these were examined as porous elements; it was reported that the compressive stress and the elasticity module of the materials related with the rate of the porosity amount and the filamentary sections were controllable and their features were relevant to the mechanic behaviors of the bone. This result reveals with this study that the alloy which is commonly used in tooth implantation in fact can also be utilized in orthopedic implants.

In the macroscopic examination of the samples taken from tibias after euthanasia, it was seen that bone tissue covered the pores within the implant and implant region itself. Although Clemow et al. [6] state that for a good bone ingrowth, the pore size of the implant material must be between 200 and $500 \mu \mathrm{m}$, the pore sizes of the implant material chosen as $85-127$ and $254 \mu \mathrm{m}$ in our study were also seen to be proper for bone ingrowth.

No immunological reaction or inflammatory cell infiltration was observed in the periosteum of the tissue samples extracted in postoperative periods. Osteoblastic activity increased, osteocytes appeared clearly in time, and at the end of observation period mature bone formation was seen in the samples. No active and chronic infection, osteitis, extraneous granules, giant cell reactions, and benign or malign neoplasm with evident tissue necrosis were reported from the bone samples taken from all cases. The results obtained showed that the Ni-Cr-Mo alloy generally was biocompatible.

\section{Acknowledgments}

This study was performed by the Firat University, Faculty of Veterinary Medicine on the formal approval of the Ethics Committee (Session Date: 22.04.2005, Decree no. 2005/5). The authors acknowledge the Scientific Research Foundation, Firat University (FUBAP_-Project no. 1018) for their financial support.

\section{References}

[1] R. Murugan and S. Ramakrishna, "Bioresorbable composite bone paste using polysaccharide based nano hydroxyapatite," Biomaterials, vol. 25, no. 17, pp. 3829-3835, 2004.

[2] F. Sarsilmaz, N. Orhan, E. Unsaldi, A. S. Durmus, and N. Colakoglu, "A polyethylene-high proportion hydroxyapatite implant and its investigation in vivo," Acta of Bioengineering and Biomechanics, vol. 9, no. 2, pp. 9-16, 2007.

[3] R. Murugan and S. Ramakrishna, "Development of nanocomposites for bone grafting," Composites Science and Technology, vol. 65, no. 15-16, pp. 2385-2406, 2005.

[4] K. Anselme, "Osteoblast adhesion on biomaterials," Biomaterials, vol. 21, no. 7, pp. 667-681, 2000.

[5] L. D. Zardiackas, L. D. Dillon, D. W. Mitchell, L. A. Nunnery, and R. Poggie, "Structure, metallurgy, and mechanical properties of a porous tantalum foam," Journal of Biomedical Materials Research, vol. 58, no. 2, pp. 180-187, 2001.

[6] A. J. T. Clemow, A. M. Weinstein, J. J. Klawitter, J. J. Koeneman, and J. J. Anderson, "Interface mechanics of porous titanium implants," Journal of Biomedical Materials Research, vol. 15, no. 1, pp. 73-82, 1981.

[7] C. E. Wen, M. Mabuchi, Y. Yamada, K. Shimojima, Y. Chino, and T. Asahina, "Processing of biocompatible porous Ti and Mg," Scripta Materialia, vol. 45, no. 10, pp. 1147-1153, 2001.

[8] E. Tsuruga, H. Takita, H. Itoh, Y. Wakisaka, and Y. Kuboki, "Pore size of porous hydroxyapatite as the cell-substratum controls BMP-induced osteogenesis," Journal of Biochemistry, vol. 121, no. 2, pp. 317-324, 1997.

[9] L. J. Gibson and M. F. Ashby, Cellular Solids: Structure and Properties, Cambridge University Press, Cambridge, UK, 1997.

[10] M. W. Christopher, M. S. Richard, J. P. F. Garry, and J. D. Alison, "Dental materials," Dental, vol. 982, p. 10, 2006.

[11] Y. Yamada, K. Shimojima, Y. Sakaguchi et al., "Processing of an open-cellular AZ91 magnesium alloy with a low density of $0.05 \mathrm{~g} / \mathrm{cm}^{3}$," Journal of Materials Science Letters, vol. 18, no. 18 , pp. 1477-1480, 1999. 
[12] Y. Yamada, K. Shimojima, Y. Sakaguchi et al., "Effects of heat treatment on compressive properties of AZ91 Mg and SG91A Al foams with open-cell structure," Materials Science and Engineering A, vol. 280, no. 1, pp. 225-228, 2000.

[13] D. T. Queheillalt, Y. Katsumura, and H. N. G. Wadley, "Synthesis of stochastic open cell Ni-based foams," Scripta Materialia, vol. 50, no. 3, pp. 313-317, 2004.

[14] M. Long and H. J. Rack, "Titanium alloys in total joint replacement-a materials science perspective," Biomaterials, vol. 19, no. 18, pp. 1621-1639, 1998.

[15] D. Curran, Metal Foams, Cambridge University Press, Cambridge, UK, 2001.

[16] B. Y. Li, L. J. Rong, Y. Y. Li, and V. E. Gjunter, "Synthesis of porous Ni-Ti shape-memory alloys by self-propagating hightemperature synthesis: reaction mechanism and anisotropy in pore structure," Acta Materialia, vol. 48, no. 15, pp. 3895-3904, 2000.

[17] S. Kujala, J. Ryhänen, A. Danilov, and J. Tuukkanen, "Effect of porosity on the osteointegration and bone ingrowth of a weightbearing nickel-titanium bone graft substitute," Biomaterials, vol. 24, no. 25, pp. 4691-4697, 2003.

[18] C. N. Cornell and J. M. Lane, "Current understanding of osteoconduction in bone regeneration," Clinical Orthopaedics and Related Research, no. 355, pp. S267-S273, 1998. 

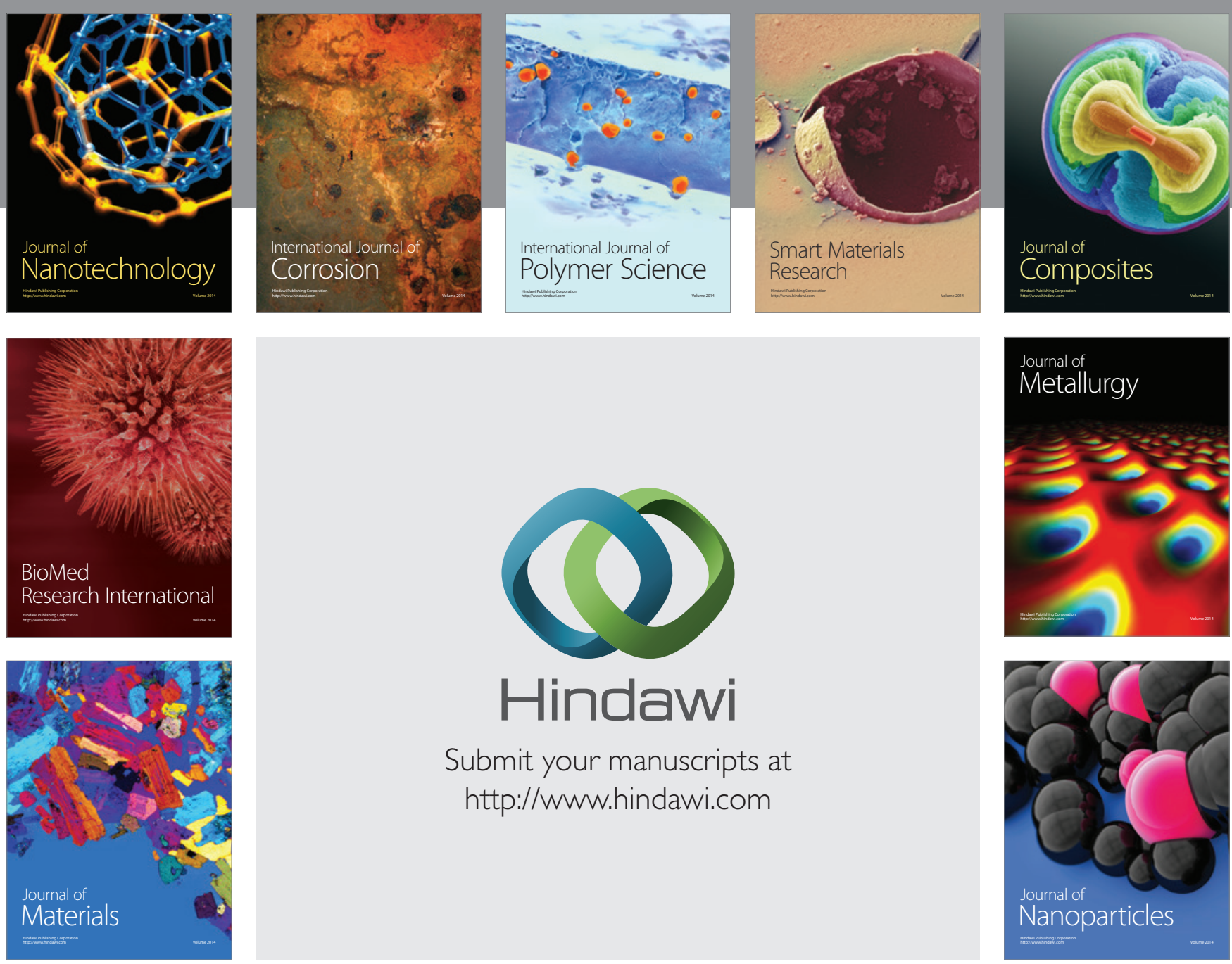

Submit your manuscripts at http://www.hindawi.com
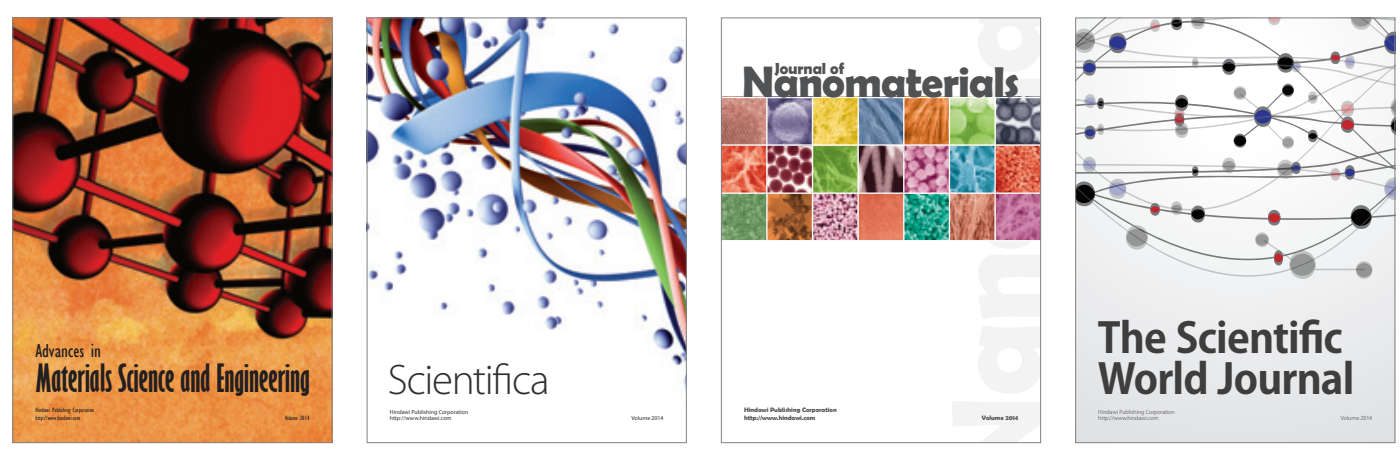

\section{The Scientific World Journal}
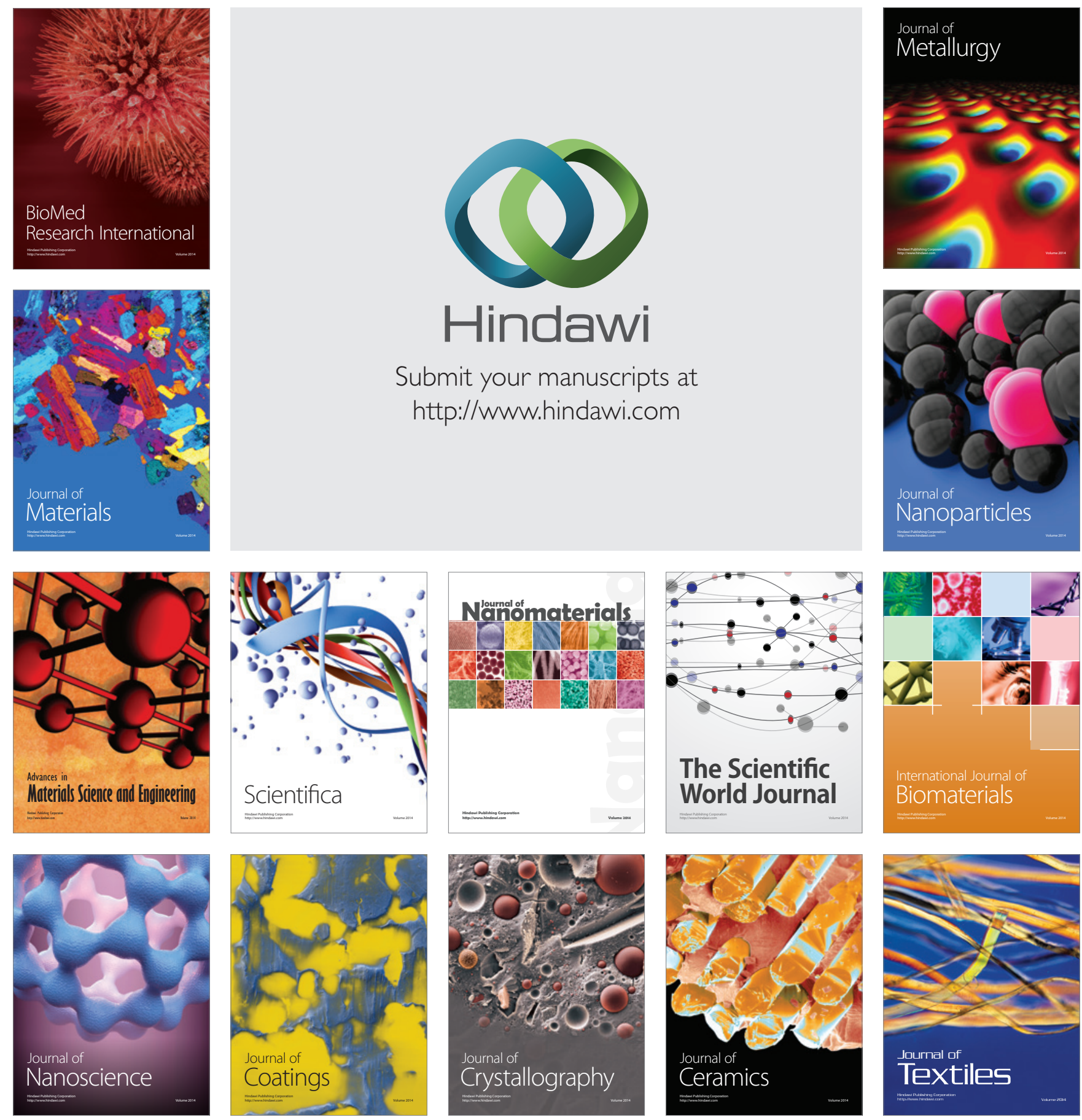